\title{
A procedure for testing potential inhibitors of human chorionic gonadotrophin activity in vivo
}

\author{
Margaret Ryle* and Jane Sage \\ Department of Clinical Endocrinology, The Birmingham and Midland Hospital for Women, \\ Showell Green Lane, Sparkhill, Birmingham B11 4HL, U.K.
}

\begin{abstract}
Summary. A procedure is described for testing potential inhibitors of hCG activity in vivo, based on a hormone-responsive alkaline phosphatase in the ovaries of young mice. Standard injections of an antiserum inhibited the response to a subsequent injection of $2 \mathrm{i} . \mathrm{u}$. hCG after an interval of up to $24 \mathrm{~h}$.
\end{abstract}

\section{Introduction}

Channing \& Bahl (1978) demonstrated that derivatives of human chorionic gonadotrophin (hCG), from which certain carbohydrate residues had been removed, bound to target cells but failed to stimulate fully their metabolic responses. Moreover, some of these derivatives acted as partial competitive inhibitors of native hormone. A competitive inhibitor for hCG might be of use for inducing abortion in the first few weeks of human pregnancy, when endometrial maintenance depends on luteal function (Csapo, Pulkkinen, Ruttner, Sauvage \& Wiest, 1972; Csapo, Pulkkinen \& Kaihola, 1974). The efficiency of potential inhibitors would depend both upon their rate of removal from the circulation (and/or inactivation) and upon their rate of loss from target-cell binding sites, relative to that of native hormone. A test system is required to examine the behaviour of potential inhibitors in vivo, in particular to estimate the duration of their effects.

Established bioassay procedures for hCG in intact animals depend on endpoints which require repeated injections of standard or test material. They are not, therefore, ideal for measuring the duration of action of a potential inhibitor. However, Bramley (1974) showed that a single injection of hCG enhanced the specific activity of an alkaline phosphatase in the ovaries of immature mice, maximal activity being reached $24 \mathrm{~h}$ after injection. This response forms the basis of the procedure described in the present paper.

\section{Materials and Methods}

Mice of two strains were used: MFI animals were purchased from Olac (1976) Ltd, Bicester, Oxfordshire, and CFW mice were bred in a laboratory colony derived from stock supplied by the M.R.C. Laboratory Animal Centre, Carshalton, Surrey. Both strains responded well to hCG when about 4 weeks old, at which age the females weighed about 17-19 $\mathrm{g}$ and 15-16 g respectively. Their responses were of similar magnitude but the two strains were not compared directly. The hCG (Pregnyl; Organon Laboratories Ltd) was dissolved and diluted in 0.9\% (w/v) $\mathrm{NaCl}$ containing $1 \%(\mathrm{w} / \mathrm{v})$ bovine serum albumin (BSA; Sigma (London) Chemical Co. Ltd)

* Present address: c/o University of Sheffield, Department of Obstetrics \& Gynaecology, Jessop Hospital for Women, Sheffield S3 7RE, U.K. 
and $0.01 \mathrm{M}$-Tris- $\mathrm{HCl}, \mathrm{pH} 7.4$. Each mouse was injected s.c. with $0.5 \mathrm{ml}$ of the appropriate solution. The composition and volume of buffer injected proved important for obtaining reproducible results although the reason for this remains unknown. The maturity and uniformity of the mice were also important for obtaining satisfactory results. The mice were killed $24 \mathrm{~h}$ after injection and the ovaries were homogenized in $1.5 \mathrm{ml}$ ice-cold $0.01 \mathrm{M}$-Tris- $\mathrm{HCl}-0.3 \mathrm{M}$-sucrose, $\mathrm{pH} 7.4$, using 20 strokes of a Teflon pestle in a glass homogenizer. The homogenates were filtered through glass wool and stored at $-20^{\circ} \mathrm{C}$. The alkaline phosphatase activity and the protein content of each sample were assayed as described by Bramley (1974), all assays being performed in triplicate. The mean spectrophotometer readings for alkaline phosphatase activity ( $\times 1000)$ were corrected for protein content but were not adjusted to an enzyme standard. Since the variability increased with increasing response the results were transformed to logarithms before comparing the means of the various experimental groups by Student's $t$ test.

A number of preliminary experiments established suitable procedures and only two definitive experiments are described below. In the first the minimal effective dose of hCG was re-checked. The second was designed to determine the period during which a single dose of an anti-hCG antiserum would prevent the normal response to a standard low dose of hCG. The antiserum used (Code F97; kindly supplied by Dr S. S. Lynch of this laboratory) was prepared for radioimmunoassay and $0.005 \mathrm{ml}$ bound approximately 1 i.u. of hormone.

\section{Results}

\section{Experiment 1}

Several experiments had shown that the short linear portion of the log dose-response curve was in the region of 1 to 2 i.u. hCG per mouse. Therefore groups of 3 MFI mice were injected with $0,0 \cdot 125,0.25,0.5,1$ or 2 i.u. hCG. The mean alkaline phosphatase response ( \pm s.e.m.) in animals which received buffer only was $0.95 \pm 0.03$. The means for $0.125,0.25$ and 0.5 i.u. $(0.83 \pm 0.06,0.87 \pm 0.06$ and $0.91 \pm 0.06$ respectively $)$ were no greater. However, the mean $\log$ response to 1 i.u. was $1.23 \pm 0.12$ and that to 2 i.u. was $1.50 \pm 0.05$, the latter being significantly greater than the controls $(P<0.001)$.

\section{Experiment 2}

Preliminary tests indicated that a suitable dose of the antiserum was $0.2 \mathrm{ml}$ of a $1: 100$ dilution, in $1 \%(\mathrm{w} / \mathrm{v}) \mathrm{BSA}$ in Eagle's tissue culture medium, $\mathrm{pH} 7.4$. Groups of CFW mice were therefore injected i.v., under light ether anaesthesia, with $1 \%$ antiserum or with BSA-medium alone at $-24,-6$ and $-1.5 \mathrm{~h}$. At $0 \mathrm{~h}$ all received 2 i.u. hCG in $0.5 \mathrm{ml}$ Tris-BSA buffer, s.c. Additional controls received only BSA-medium at $-24,-6$ and $-1.5 \mathrm{~h}$ and Tris-BSA buffer without hormone at $0 \mathrm{~h}$. Three mice were allocated to each group which received antiserum and 2 to each of the others. Four extra controls received Tris-BSA only at $0 \mathrm{~h}$ and were included to check for possible effects of ether anaesthesia. All animals were killed at $+24 \mathrm{~h}$ and ovarian alkaline phosphatase activity was estimated.

The activity in animals injected only with buffers was uniform, the pooled mean log response ( \pm s.e.m.) being $0.72 \pm 0.03(n=10)$. The responses of those injected with BSA-medium followed by hCG were not systematically affected by the timing of the earlier injection and the pooled mean, $1.36 \pm 0.07(n=6)$ was significantly different from that of the 'buffer only' group $(P<0.001)$. The mean $\log$ response of the 3 mice injected with antiserum $1.5 \mathrm{~h}$ before hCG was $0.74 \pm 0.06$ and that for the 6 -h group was $0.70 \pm 0.04$; i.e. both were similar to the "buffer only' values. The $\log$ responses of 2 of the 3 mice in the 24 -h group were also in the 'buffer only' range $\left(0.64\right.$ and 0.69 but the third $(1.18)$ was in the 'bCG ${ }_{-1}$ no antiserum' range. 


\section{Discussion}

Since no competitive inhibitor was available to test the system, an arbitrary dose of a specific antiserum was used. The results indicate that for about $24 \mathrm{~h}$ after i.v. injection the concentration remaining in the circulation was sufficient to suppress the effect of a relatively small dose of hCG. It is concluded that similar procedures should be suitable for estimating the duration of the effects of other potential inhibitors of responses to hCG.

\section{References}

Bramley, T.A. (1974) Treatment of immature mice with gonadotrophins. Effects on some enzymic activities of unfractionated ovarian homogenates. Biochem. $J$. $140,451-460$.

Channing, C.P. \& Bahl, O.P. (1978) Role of carbohydrate residues of human chorionic gonadotrophin in stimulation of progesterone secretion by cultures of monkey granulosa cells. Biol. Reprod. 18, 707711.
Csapo, A.I., Pulkkinen, M.O., Ruttner, B., Sauvage, J.P. \& Wiest, W.G. (1972) The significance of the human corpus luteum in pregnancy maintenance. 1. Preliminary studies. Am. J. Obstet. Gynec. 112 , 1061-1067.

Csapo, A.I., Pulkkinen, M.O. \& Kaihola, H.L. (1974) The relationship between the timing of luteectomy and the incidence of complete abortions. Am. J. Obstet. Gynec. 118, 985-989. 